\title{
AGRICULTURE
}

\section{PHYTOHORMONAL ACTIVITY OF IMMOBILIZED CELLS OF SALT-TOLERANT COTTON RHIZOBACTERIA AFTER LONG TERM STORAGE}

\author{
Zakiryaeva Saidakhon Ikramovna \\ The Institute of Microbiology, Academy of Sciences of the Republic of Uzbekistan, Tashkent
}

DOI: https://doi.org/10.31435/rsglobal_wos/31032020/6999

\section{ARTICLE INFO}

Received: 10 January 2020

Accepted: 16 March 2020

Published: 31 March 2020

\section{KEYWORDS}

Free and immobilized cells, cotton rhizobacteria, phytohormonal activity, auxin, gibberellin, Indole-3-Acetic Acid.

\begin{abstract}
The phytohormonal activity of free and immobilized cells of $\mathrm{B}$. subtilis BS-80, B. licheniformis BL-83, P. polymyxa PP-113 and P. amylolyticus PA-118 on phosphate flour have been studied. It was found that immobilized cells more actively synthesized IAA and gibberellins in comparison with free cells. The data obtained indicates that the phytohormonal activity of the salt-resistant cells of cotton rhizobacteria can be kept much better in the immobilized form than in the free form (in a refrigerator on jambs).
\end{abstract}

Citation: Zakiryaeva S. I. (2020) Phytohormonal Activity of Immobilized Cells of Salt-Tolerant Cotton Rhizobacteria After Long Term Storage. International Academy Journal Web of Scholar. 3(45). doi: 10.31435/rsglobal_wos/31032020/6999

Copyright: (C) 2020 Zakiryaeva S. I. This is an open-access article distributed under the terms of the Creative Commons Attribution License (CC BY). The use, distribution or reproduction in other forums is permitted, provided the original author(s) or licensor are credited and that the original publication in this journal is cited, in accordance with accepted academic practice. No use, distribution or reproduction is permitted which does not comply with these terms.

Phytohormones are compounds by means of which the interaction are realized in cells, tissues and organs of plants and which in small quantities are necessary for the start and regulation of physiological and morphogenetic processes - the main functions of the plant organism.

Phytohormones are involved in the processes of growth, development (differentiation), transportation of nutrients, and control the reactions of plants to various stresses, etc. The phytohormones include gibberellins, auxins, cytokinins, ethylene, as well as abscisic and Jasmine acids, fusicoccins, etc. In their chemical composition, plant hormones belong to phenols, terpenoids, pyrones and other chemical compounds [1].

Most phytohormones are formed by plants themselves, but often these compounds are found first in microorganisms interacting with plants, and only then in plant cells.

Many microorganisms associated with plants are able to synthesize substances of phytohormonal nature, which are necessary for their own development, and to establish connections with plants and other soil microorganisms. The formation of hormones is one of the important properties of rhizospheric bacteria that stimulate plant growth.

Auxin activates the cell division and stretching, it is necessary for the formation of conductive beams and roots, promotes the growth of the pericarp. Tissue enriched with auxin, have outragerous effect, i.e. the ability to attract nutrients. The main auxin in the plant body is indolyl-3-acetic acid, but many other compounds also have auxin activity [1].

The rhizospheric microflora of plants plays a primary role in the transformation of tryptophan into IAA contained in root exudates. In a nutrient medium without tryptophan microorganisms are characterized by low level of production of IAA, with the introduction of exogenous tryptophan, the yield of phytohormone increases tenfold as $80-100 \mu \mathrm{g} \mathrm{IAA} / \mathrm{ml}$ in the culture medium in the most active strainsproducers. The most highly effective producers of auxins are found among microorganisms living in the 
rhizosphere and phyllosphere of plants [2-4]. The maximum amount of IAA is formed by bacteria in the stationary phase of growth, and ammonium ions and glutamine inhibit the biosynthesis of IAA [5,6].

In plants, IAA binds to sugars, amino acids, proteins, forming spare forms, from which the phytohormone is released if necessary. Inactivation and metabolism of IAA occurs with IAA - or polyphenol oxidase. IUK-oxidase functions are performed by certain molecular isoforms of peroxidase [7].

The formation of gibberellins is peculiar to epiphytic and rhizospheric bacteria, which are representatives of the genera Azotobacter, Azospirillum, Pseudomonas, Bacillus, Flavobacterium, Clostridium, Agrobacterium [2].

An important advantage of immobilized cells is the preservation of their viability and metabolic activity for a long time.

Thus, the aim of this study was to study the phytohormonal activity of the cells of saltresistant rhizobacteria of cotton immobilized on phosphate flour after a long term (4 years) storage.

The objects of the research were followings: free cells of rhizobacteria of cotton - Bacillus subtilis BS-80, B. licheniformis BL-83, Paenibacillus polymyxa PP-113, P. amylolyticus PA-118, those were stored at periodic subculturing, and immobilized cells of rhizobacteria of cotton $-B$. subtilis BS-80, B. licheniformis BL-83, P. polymyxa PP-113, P. amylolyticus PA-118, which were stored for 4 years on phosphate rock.

Monoculture of phosphor-mobilizing rhizobacteria were cultivated using depth method at a temperature of $28-29{ }^{\circ} \mathrm{C}$ on a nutrient medium (peptone water, glucose and $\mathrm{NaCl}$ ).

Immobilization of rhizobacteria cells have been performed by the method of adsorption immobilization. Grown to the stationary phase of bacterial suspension of phosphor-mobilizing rhizobacteria (in the amount $15 \mathrm{ml}$ ) was mixed with sterile carrier $(50 \mathrm{~g})$ in a ratio of $1: 7$, previously determined titer of the introduced cells. The resulting slurry was dried in a drying cabinet at $40{ }^{\circ} \mathrm{C}$ for 2 hours [8]. After drying, the finished dry preparation was stored in a closed form at room temperature.

Quantitative determination of phytohormones was performed by colorimetric methods. The definition of the production of indole-3-acetic acid was carried out according to the method of Gordon and Weber [9], the determination of gibberelin synthesis was carried out according to the method of Muromtsev and Nastuk [10].

During statistical processing, the arithmetic mean and standard deviation, confidence intervals were determined using student's test. The differences were considered as reliable at the significance level $p \leq 0,05$ [11].

An important characteristic of immobilized cells that distinguishes them from free cells is long-term functional activity.

Table 1 shows the phytohormonal activity of free and immobilized on phosphate rock cells of cotton rhizobacteria after a long shelf life.

From the data presented in the table displayed that that immobilized on phosphate rock cells B. subtilis BS-80 more actively isolated IAA and gibberellins, compared with free cells. Also cells that immobilized on phosphate rock B. subtilis BS- 80 more actively and stably isolated IAA and gibberellins, compared with other immobilized cells of cultures B. licheniformis BL-83, P. polymyxa PP-113 and P. amylolyticus PA-118. The best results showed by cells B. subtilis BS-80 immobilized on phosphate rock, synthesis of IAA phytohormone on the 7th day of the experiment was $40.3 \pm 0.3 \mu \mathrm{g} / \mathrm{ml}$, while free cells of this strain have synthesized only $18.03 \pm 0.20 \mu \mathrm{g} / \mathrm{ml}$. High production of gibberellins in immobilized cells $B$. subtilis BS- 80 was observed on the 7 th day of the experiment as $884.2 \pm 1.15 \mu \mathrm{g} / \mathrm{ml}$, free cells for $430.3 \pm 1.18 \mu \mathrm{g} / \mathrm{ml}$.

A different pattern was observed in rhizobacteria B. licheniformis BL-83, immobilized $(30,7 \mu \mathrm{g} / \mathrm{ml})$ and free $(29,5 \pm 0,15 \mu \mathrm{g} / \mathrm{ml})$ cells of $B$. licheniformis BL-83 have actively isolated the IAA on the third day of the experiment. By the seventh day of the experiment, immobilized cells of this strain synthesized the phytohormone IAA twice less $(14.7 \mu \mathrm{g} / \mathrm{ml})$, compared with the third day of the experiment, and free cells did not produce IAA at this time. For the production of gibberellins, the best results showed by the immobilized cells of B. licheniformis BL-83 on the 7th day of the experiment $-430,5 \mathrm{mcg} / \mathrm{ml}$, where free cells $-399.5 \pm 1,21 \mu \mathrm{g} / \mathrm{ml}$. P. polymyxa PP-113 cells that immobilized on phosphate flour have been actively isolated the IAA on the 3rd day of the experiment - up to $24.1 \pm 0.26 \mu \mathrm{g} / \mathrm{ml}$, while free cells up to $21.4 \pm 0.12 \mu \mathrm{g} / \mathrm{ml}$. High production of gibberellins in immobilized $(768.8 \pm 0.61 \mu \mathrm{g} / \mathrm{ml})$ and free cells $(738.0 \pm 0.58 \mu \mathrm{g} / \mathrm{ml})$ P. polymyxa PP-113 has been observed on the 3rd day of the experiment. Immobilized cells have produced gibberellin for $30.8 \mu \mathrm{g} / \mathrm{ml}$ more than free cells. 
Table 1. Production of IAA and gibberellins by free (FR) and immobilized (IM) cells on phosphate flour of cotton rhizobacteria $(\mathrm{mcg} / \mathrm{ml})$

\begin{tabular}{|l|c|c|c|}
\multirow{2}{*}{$\begin{array}{c}\text { Cells of salt-tolerant and phosphor- } \\
\text { mobilizing rhizobacteria }\end{array}$} & \multicolumn{3}{|c|}{ IAA } \\
\cline { 2 - 4 } & 3 & 5 & 7 \\
\cline { 2 - 4 } & $15,3 \pm 0,30$ & $16,7 \pm 0,22$ & $18,7 \pm 0,25$ \\
\hline FR - B. subtilis $B S-80$ & $26,8 \pm 0,40$ & $28,2 \pm 0,38$ & $40,3 \pm 0,32$ \\
\hline IM - B. subtilis BS-80 & $29,5 \pm 0,37$ & $14,7 \pm 0,21$ & 0 \\
\hline FR - B. licheniformis BL-83 & $30,7 \pm 0,41$ & $17,4 \pm 0,27$ & $14,7 \pm 0,26$ \\
\hline IM - B. licheniformis BL-83 & $21,4 \pm 0,12$ & $15,3 \pm 0,18$ & $13,3 \pm 0,23$ \\
\hline FR - P. polymyxa PP-113 & $24,1 \pm 0,26$ & $16,7 \pm 0,23$ & $14,7 \pm 0,29$ \\
\hline IM - P. polymyxa PP-113 & $9,32 \pm 0,09$ & $9,24 \pm 0,06$ & $11,3 \pm 0,06$ \\
\hline FR - P. amylolyticus $P A-118$ & $13,3 \pm 0,17$ & $9,92 \pm 0,10$ & $12,0 \pm 0,15$ \\
\hline IM - P. amylolyticus $P A-118$ & Gibberellins & \\
\hline & $430,3 \pm 0,26$ & $291,9 \pm 0,16$ & $1068,8 \pm 0,76$ \\
\hline FR - B. subtilis BS-80 & $786,8 \pm 0,23$ & $384,2 \pm 0,26$ & $1153,4 \pm 0,84$ \\
\hline IM - B. subtilis BS-80 & $307,2 \pm 0,16$ & $291,9 \pm 0,23$ & $399,5 \pm 0,32$ \\
\hline FR - B. licheniformis BL-83 & $430,3 \pm 0,32$ & $307,2 \pm 0,30$ & $430,3 \pm 0,24$ \\
\hline IM - B. licheniformis BL-83 & $738,0 \pm 0,58$ & $291,9 \pm 0,16$ & $311,5 \pm 0,46$ \\
\hline FR - P. polymyxa PP-113 & $768,8 \pm 0,61$ & $305,7 \pm 0,23$ & $384,2 \pm 0,50$ \\
\hline IM - P. polymyxa PP-113 & $104,2 \pm 0,15$ & $276,5 \pm 0,26$ & $322,6 \pm 0,35$ \\
\hline FR - P. amylolyticus $P A-118$ & $138,0 \pm 0,29$ & $291,9 \pm 0,32$ & $338,6 \pm 0,38$ \\
\hline IM - P. amylolyticus $P A-118$ & \multicolumn{3}{|c|}{} \\
\hline
\end{tabular}

Immobilized on phosphate flour cells of P. amylolyticus PA-118 activly isolated IAA on the 3rd day of the experiment, in comparison with the free cells to $13.3 \pm 0,23 \mu \mathrm{g} / \mathrm{ml}$, whereas free cells to $9.32 \pm 0.05 \mathrm{mg} / \mathrm{ml}$. High production of gibberellins at immobilized $(368,6 \mu \mathrm{g} / \mathrm{ml})$ and free $(322,6 \pm 1,15 \mu \mathrm{g} / \mathrm{ml})$ cells of $P$. amylolyticus PA-118 has been observed on the 7 th day of the experiment.

Thereby, the study of phytohormonal activity of free and immobilized cells on phosphate flour cells of B. subtilis BS-80, B. licheniformis BL-83, P. polymyxa PP-113 and P. amylolyticus PA-118 revealed that the immobilized cells more actively synthesized IAA and gibberellins compared with free cells. The data obtained indicates that the salt-resistant cells of rhizobacteria of cotton in the immobilized form of phytohormonal activity is preserved better than in the free form (in a refrigerator on jambs). Apparently, this is due to the fact that immobilized microorganisms in comparison with free ones are characterized by high catalytic activity, increased viability and resistance to adverse environmental factors.

\section{REFERENCES}

1. Polevoy V. V. Plant Physiology. M., "Higher school". 1989. 464 PP (In Russian).

2. Tsavkelova E. A., Klimova S. Yu., Cherdyntsev T. A., Netrusov A. I. Hormones and hormone-like compounds of microorganisms // Applied biochemistry and microbiology. — 2006. — 42, № 3. — P. 261268. (In Russian).

3. Kravchenko L. V., Azarova T. S., Makarova N. M., Tikhonovich I. A. The role of tryptophan in root exometabolites for phyto-stimulating activity of rhizobacteria. Microbiology. — 2004. — 73, № 2. — P. 195-198. (in Russian).

4. Morgun V. V., Kots S. Ya., Kirichenko E. V. Growth-stimulating rhizobacteria and their practical application // Physiology and biochemistry cult. plants'. 2009. Vol. 41. No. 3. P. 187-207. (in Russian).

5. Cozzolino L., Rufolo A., Zeina A. et al. Biocontrol activity of Bacillus spp. strains isolated from the rhizosphere of vegetable crops // J. Plant Pathol. — 2005. - 87, N 4. Spec. Issue. -P. 292.

6. Kang S. H., Cho K. K., Bok, J. D. et al. Cloning, sequencing and characterization of a novel phosphatase gene, phoI, from soil bacterium Enterobacter sp.4 // Curr. Microbiol. — 2006. — 52, N 4. — P. 243-248.

7. Derfling K. Hormones of the plants. Systematical approach. - M.: Mir, 1985. - 304 p. (In Russian).

8. Kurdish I. K. Granular microbial preparations for crop production: Science and practice. Kiev. 2001.142 PP. (In Russian).

9. Gordon S. A., Weber R. P. Colometric estimation of indol acetic acid // Plant Physiol., 1951. - Vol. 26. - P. 192-195.

10. Muromtsev G. S., Nestiuk M. M. Method of quantitative determination of gibberellins // Bulletin of inventions, 1960. - №60. (in Russian).

11. Larkin M. A., Blackshields G., Brown N. P., Chenna R. and et al. Version 2.0. Bioinformatics, 2007. Vol. 23. - P. 2947-2948. 